\title{
Perceptions and attitudes of local people towards participatory forest management in Tarmaber District of North Shewa Administrative Zone, Ethiopia: the case of Wof-Washa Forests
}

\author{
Solomon Ayele Tadesse ${ }^{1 *}$ and Demel Teketay ${ }^{2}$
}

\begin{abstract}
Introduction: Since the last few decades, the government of Ethiopia has introduced and adopted participatory forest management (PFM) in different regions of the country. However, there is a lack of research dealing with perceptions and attitudes of local people towards PFM in Wof-Washa Forests (WWF). The aim of this study was to evaluate the perceptions and attitudes of local people towards PFM implemented in WWF. We hypothesized that the perceptions and attitudes of local people towards PFM differ with socio-economic variables, such as sex, age, level of education, family size, occupation type, annual income, length of duration of local residence, livestock, and land ownership.

Methods: A structured questionnaire comprised of close- and open-ended questions was developed and administered to a total of $n=64$ households to collect information on the perceptions and attitudes of local people towards PFM in WWF. Descriptive statistics and multiple linear regressions were used to analyze and interpret the data.

Results: The results revealed that socio-economic variables had significant effects on the perceptions towards "the prevalence of the problems with the existing PFM system" (39\% variance explained), "the concept of PFM" (30\% variance explained), and "the presence of PFM practice" (11\% variance explained). Majority of the respondents accepted the PFM program introduced in WWF in order to protect and manage the WWF. The study also revealed that socio-economic variables had significant effects on the attitudes towards "managing forests via participatory approach" (16\% variance explained), "having the responsibility to protect the WWF" (40\% variance explained), and "accepting the PFM practice" (54\% variance explained). However, the findings suggested that there were some respondents who were yet unsure to fully accept the concept and practice of PFM.

Conclusions: Creating public awareness about PFM is crucial to alleviate the problems of deforestation and reduce the unsustainable use of the WWF. As socio-economic variables that affect perceptions and attitudes of local people towards PFM may change over time, future research is crucial to consider the time dimension as possible factor while studying perceptions and attitudes of local people towards PFM.
\end{abstract}

Keywords: Deforestation, Respondents, Socio-economic variables, Structured questionnaire, Wof-Washa Forests

\footnotetext{
* Correspondence: solomon.ayele1972@gmail.com

${ }^{1}$ Department of Natural Resources Management, College of Agriculture and

Natural Resource Sciences, Debre Berhan University, P.O. Box 445, Debre

Berhan, Ethiopia

Full list of author information is available at the end of the article
} 


\section{Introduction}

Human benefits are reliant on forests for regulating and supporting cultural and provisional services in many cases. However, the areas of forest resources are declining across the globe, partly, as a result of commercial logging and conversion of forested habitats to crop lands. For example, agricultural land expansion driven by the indiscriminate clearance of forests is estimated to account for $43 \%$ of tropical forest losses (Daily 1995). This suggests that tropical forests are being destroyed at an alarming rate all over the world. For instance, more than 5 million hectares of forests are being converted into poorly managed secondary vegetation annually (CIFOR 2001). As a way to reduce forest degradation in different parts of the world, collaboration between different stakeholders has been developed. For example, several countries in Latin America, Asia, and Africa are shifting the responsibilities for managing natural resources to municipal governments (CIFOR 2001).

The forest resources in Ethiopia have been continuously declining over time. They have declined significantly and steadily both in size and quality, e.g., in species composition and structure. In the past, forests were managed by the government without the participation of local communities. Local communities are often rich in indigenous knowledge and appreciation of their natural and cultural heritages. Pressure for rapid economic development, however, can alienate people from their heritage and degrade the local environment. For example, lack of public awareness, negative attitudes, and absence of an economic benefit-sharing mechanism from the forest resources to the local people have contributed much to the loss of forests in Ethiopia (Hillman 1993; Tesfaye 2011; Tesfaye et al. 2012; Ameha et al. 2014).

To overcome the prevailing and pressing problems or at least to minimize the magnitude of the deriving factors, the development actors, mainly, non-governmental organizations (NGOs) have introduced the concept of participatory forest management (PFM) in some parts of Ethiopia (Irwin 2000; Winberg 2010). Participation of local people in forest conservation can vary from outreach that acknowledges community concerns to full delegation of conservation and management authority to the local people (Nelson and Wright 1995). For example, Sahal and FARM-Africa were the NGOs that pioneered the current participatory natural resource and forest management initiatives in Ethiopia (Anders 2000). PFM is a strategy to achieve sustainable forest management by encouraging the management of forests and woodland resources by the communities living in and around the resources. PFM is recommended to contribute towards improving food security and poverty reduction in Ethiopia (Kelley and Scoones 2000). It could, therefore, have the potential to play in reaching three of the Sustainable Development Goals (see Table 1). As the local people who live, especially, in the developing countries, like Ethiopia, mostly depend on the direct use of natural resources, including forests, achieving the three Sustainable Development Goals (see Table 1) will affect the conservation, sustainable utilization, and management of the forest resources. For example, a case study conducted by Tesfaye et al. (2010) in southeastern Ethiopia found that the contribution of forests to the average total annual household income was $23-53 \%$, depending on income quintile. Thus, social interactions that are crucial for effective PFM implementation include empowerment, involvement, negotiation, and collective decision-making (Kelbessa and Destoop 2007).

The successful conservation of forests is dependent upon the attitudes of the local people who are inherently connected with the forests and through their active participation in forest management (Hillman 1993; Tesfaye 2011; Tesfaye et al. 2012; Ameha et al. 2014; Siraj et al. 2016). Several studies also noted that previous benefits and values can affect the conservation attitudes of the local people towards forest conservation and management (e.g., Fiallo and Jacobson 1995; Gillingham and Lee 1999; Walpole and Goodwin 2001; Gadd 2005; Kideghesho et al. 2007; Tesfaye 2011; Tesfaye et al. 2012; Ameha et al. 2014; Siraj et al. 2016). According to Oskamp (1977), values refer to things that people consider being precious so that they are the most important and central elements in a person's system of attitudes and beliefs.

Attitudes are positive or negative responses of people towards a certain activity (e.g., PFM) (Jotte 1997; Elias 2004; Tesfaye 2011; Tesfaye et al. 2012). Thus, negative or positive attitudes of local people towards PFM will likely affect their contribution and participation in the conservation and management of forests (Tesfaye 2011; Tesfaye et al. 2012; Ameha et al. 2014; Siraj et al. 2016). Behavior of people can be influenced by their perceptions (i.e., knowledge and experience) about phenomena (e.g., forest resources) (Jotte 1997; Woltamo 1997). Attitudes of local people can be affected by their behaviors (Jotte 1997). So, understanding how behavior affects the attitudes of people is of paramount importance for the conservation and sustainable utilization of the forest resources through the introduction and implementation of PFM, especially in the developing countries, like Ethiopia, where the local people are directly dependent on the forest resources to

Table 1 Three of the Sustainable Development Goals

Goal 1: End poverty in all its forms everywhere.

Goal 2: End hunger, achieve food security and improved nutrition and promote sustainable agriculture.

Goal 15: Sustainably manage forests, combat desertification, halt and reverse land degradation, halt biodiversity loss. 
satisfy their livelihoods (Jotte 1997; Tesfaye et al. 2010; Tesfaye et al. 2012; Ameha et al. 2014; Siraj et al. 2016).

Previous studies suggested that the perception and attitudes of local people towards PFM were affected by socio-economic variables, such as sex, age, level of education, occupation type, length of local residence, land and livestock ownership, income level, grazing land ownership, and plan to stay in the area in the future (e.g., Mehta and Kellert 1998; Gillingham and Lee 1999; Mehta and Heinen 2001; Gellich et al. 2005; Husain and Bhattacharya 2004; Kideghesho et al. 2007; Lee et al. 2009; Tesfaye et al. 2010; Tesfaye 2011; Tesfaye et al. 2012; Takahashi and Todo 2012; Ameha et al. 2014; Tadesse and Kotler 2016). Moreover, perception and attitudes of local people towards PFM are influenced by previous benefits (access to and control over resources) due to PFM implementation in the area, knowledge of respondents about past forest management system, knowledge and experience of respondents about PFM implementation, knowledge of the respondents about the problem with the existing PFM system, distance from the edge of the forest and the residential area of the respondents, tree planting and growing tradition, and interests of the respondents about managing forests via participatory approach (e.g., Oskamp 1977; Pongquan 1992; Woltamo 1997; Hills 1995; Knight et al. 2004; Roskaft et al. 2007; Winberg 2010; Tesfaye 2011; Tesfaye et al. 2012; Takahashi and Todo 2012; Ameha et al. 2014; Mamo 2015; Siraj et al. 2016; Tadesse and Kotler 2016).

Tarmaber District is one of the districts in North Shewa Administrative Zone of the Amhara National Regional State (ANRS) in Ethiopia, where PFM has been instated as a project so as to protect and manage the Wof-Washa Forest (WWF). This is due to the fact that the local people are more or less interested in seeing the introduction and implementation of PFM in WWF. Even though several studies have been carried out focusing on PFM in different parts of Ethiopia (e.g., Elias 2004; Kelbessa and Destoop 2007; Winberg 2010; Tesfaye 2011; Tesfaye et al. 2012; Siraj et al. 2016), with special emphasis to the evaluation of perceptions and attitudes of local people towards PFM, no such studies have been conducted in WWF, which is located in Tarmaber District.

The objective of this study was, therefore, to examine the perceptions and attitudes of local people towards the PFM introduced and implemented in Tarmaber District by focusing on WWF as a case study. To meet this objective, the following two hypotheses were tested: (i) socio-economic variables, such as sex, age, level of education, length of local residence, land and livestock ownership, income level, grazing land ownership, and plan to stay in the area in the future help predict perceptions and attitudes of local people towards PFM; and (ii) there are variations in perceptions and attitudes of local people towards PFM depending on previous benefitsharing (i.e., access to and control over the forest resources), knowledge of respondents about past forest management system, knowledge and experience of respondents about PFM implementation, knowledge of the respondents about the problem with the existing PFM system, distance from the edge of the forest and the residential area of the respondents, and tree planting and growing tradition.

\section{Methods}

Study area

The study was conducted in Wof-Washa Kebele ${ }^{1}$ of Tarmaber District, which is found in North Shewa Administrative Zone of the ANRS and located at $9^{0} 84^{\prime}$ $91^{\prime \prime} \mathrm{N}$ and $39^{\circ} 73^{\prime} 23^{\prime \prime} \mathrm{E}$. It is situated about 60 and $132 \mathrm{~km}$ from Debre Berhan town and Addis Abeba, respectively. It covers an area of 54,000 ha and has an estimated total population size of 84,481 people of whom 42,812 were males and 41,669 were females. The area has a mean annual temperature and rainfall of about $15.5{ }^{\circ} \mathrm{C}$ and $1200 \mathrm{~mm}$, respectively. The altitude of the area ranges between 1500 and $3100 \mathrm{~m}$ (Teketay and Bekele 1995). The study forest, i.e., Wof-Washa Forest (WWF), is located in North Shewa Administrative Zone (about $9^{\circ} 45^{\prime} \mathrm{N}$ and $39^{\circ} 45^{\prime} \mathrm{E}$ ), central highlands of Ethiopia, some $160 \mathrm{~km}$ Northeast of Addis Abeba (Fig. 1). There are different opinions about the size of the WWW. For example, previous researchers estimated that WWF was thought to cover an area of 3500 ha (Von Breitenbach 1962; Henery 1973; Chaffey 1979). However, FAO (1988) estimated that the forest covers an area of 10,000 ha. These differences suggested the need for further investigations about the exact boundary of the WWF. However, the forest is under steady human and livestock pressures which are believed to reduce the area of the WWF as time goes on (Teketay and Bekele 1995). Some of the common woody species in WWF include Juniperus procera Hochst. ex Endl, Afrocarpus falcatus Thunberg, Polyscias fulva (Hiern) Harms, Hypericum revolutum Vahl, Ekebergia capensis Sparrm., Bersama abyssinica Fresen., Olea hochstetteri Bak., Celtis africana Burm.f., Hagenia abyssinica (Bruce) Gmel., and Prunus africana (Hook. f.) Kalkm. (Bekele 1994; Teketay and Bekele 1995).

\section{Development of the instrument}

We developed a structured questionnaire by considering the various socio-economic and cognition variables (e.g., knowledge, beliefs, and experience) (Tesfaye et al. 2012; Mamo 2015; Tadesse and Kotler 2016) that likely affect the perceptions and attitudes of local people towards the PFM implemented in WWF. Most socio-economic, 


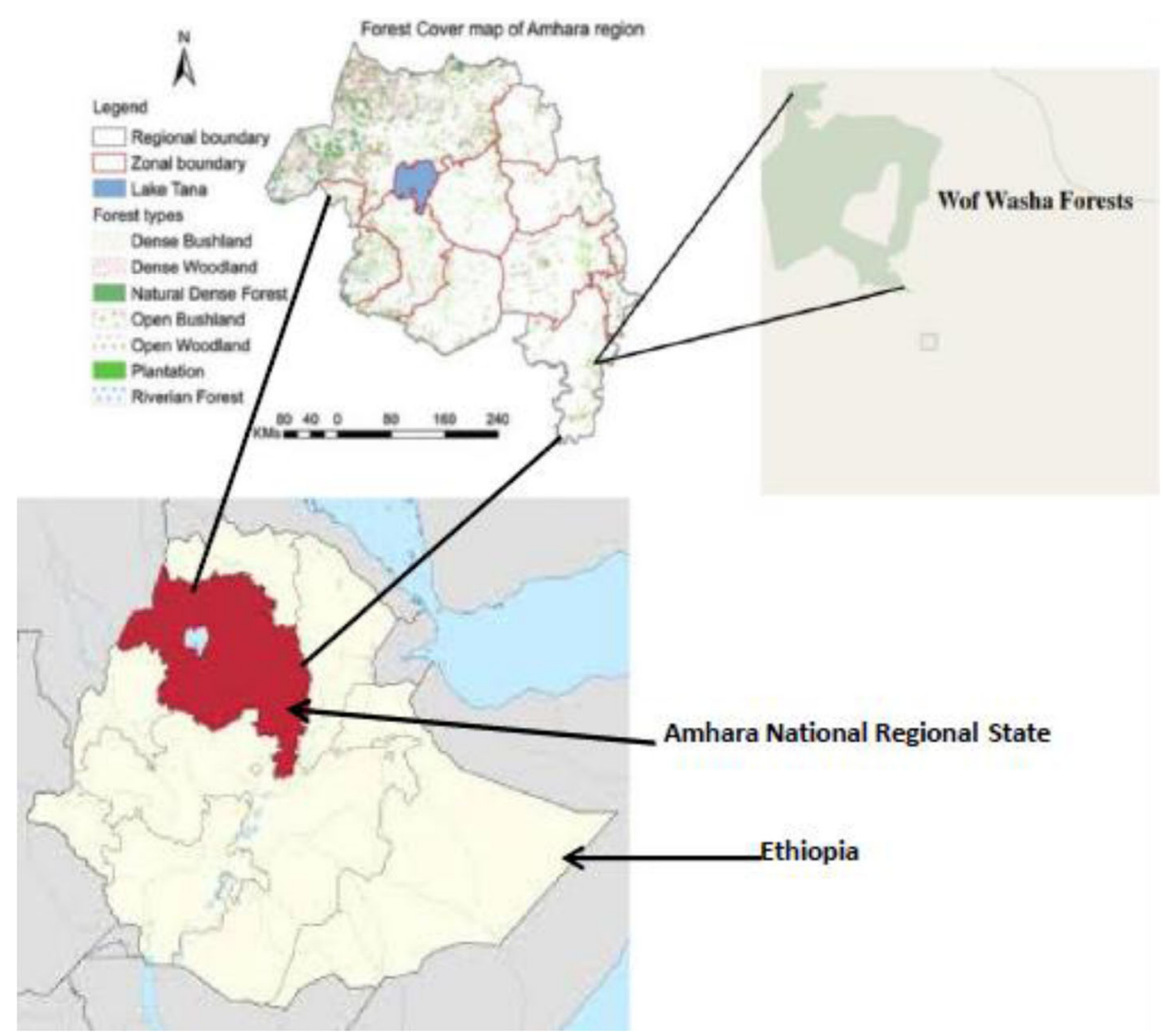

Fig. 1 Map showing the location of the Wof-Washa Forests in Amhara National Regional State

knowledge, and experience measuring questions were measured in nominal scale and rated using $3=$ yes, 2 $=$ unsure, and $1=$ no. Distance between the residential area of the respondents and the edge of the WWF, age, family size, annual income, level of education, and length of residence in the area were measured in continuous quantitative values. Information on previous benefit-sharing (i.e., access to and control over the WWF), allocation of land for woodlot plantations, and tree planting and growing tradition was measured in nominal scale and rated using $3=$ yes, $2=$ unsure, and $1=$ no. Questions dealing with the perceptions of the respondents towards "the concept of PFM," "implementation of PFM," and "problems with the existing PFM system" were also measured in nominal scale and rated using $3=$ yes, $2=$ unsure, and $1=$ no. Larger values expressed greater perception towards PFM. For the supplementary open-ended questions, the respondents narrated their experiences and knowledge about PFM. However, questions addressing the attitudes of local people towards "managing WWF through participatory approach," "having the responsibility to protect WWF," and "accepting the concept and practice of PFM" were measured by employing Likert scale and rated using $5=$ strongly agree, $4=$ agree, $3=$ unsure, $2=$ disagree, and $1=$ strongly disagree through the structured questionnaire survey (Cohen et al. 2000; Hren et al. 2004). Larger values reflected positive attitudes towards PFM.

\section{Data collection}

The local people in the study site are historically linked to the WWF and are knowledgeable about the forest resource existing in the area. More importantly, they can affect the forest because of their direct dependence on it for fuelwood, construction materials, wood products sold by households, and free-range livestock grazing (Teketay and Bekele 1995). Hence, the successful conservation of the WWF depends on perceptions and attitudes of the local people who are inherently connected with the local landscape (Hillman 1993; Tesfaye et al. 2012) and through their active participation in its management.

Based on its proximity to the boundary of the WWF, Wof-Washa Kebele was purposively selected for the study owing to the implementation of PFM in WWF. In order to collect the required data for the study, a structured questionnaire containing close- and open-ended questions was developed and administered to a total of 64 randomly selected households. The households were 
randomly selected through a lottery system based on their house identification numbers. The response rate was $100 \%$ because the data enumerators conducted the questionnaire survey via direct house-to-house visits. The data collected helped in testing the two hypotheses by examining how the different socio-economic and cognition variables were correlated and affected the dependent variables, such as perceptions and attitudes of local people towards the PFM implemented in the study site. The data were collected in May 2016.

\section{Independent variables}

Independent variables were derived from the following 20 questions: (i) sex, (ii) age, (iii) level of education, (iv) family size, (v) occupation type, (vi) annual income, (vii) livestock ownership, (viii) enough grazing land, (ix) desire to keep more livestock than had at present, (x) shortage of fodder for their livestock, (xi) length of duration of residence in the area (in years), (xii) history of settlement in the area, (xiii) plan to stay in the area in the future, (xiv) private land ownership, (xv) allocated land for woodlot plantations, (xvi) shortage of fuelwood, (xvii) benefited due to PFM, (xviii) knowledge of the respondents on WWF, (xix) distance between the edge of the WWF and the residential area of the respondent, and $(\mathrm{xx})$ tree planting and growing tradition.

\section{Dependent variables}

The dependent variables were derived from the following six statements: (i) perception towards the concept of PFM, (ii) perception towards "the presence of PFM practice," (iii) perception towards "problems with the existing PFM system," (iv) attitude towards "having the responsibility to protect the forest," (v) attitude towards "accepting the PFM practice"; and (vi) attitude towards "managing forests via participatory approach."

\section{Data analyses}

The raw data were analyzed using descriptive statistics and summarized into tabular format. Multiple linear regression model [significance level of $\alpha=0.05$ ] was used to analyze and predict the values of the dependent variables, i.e., perceptions and attitudes of the local people. After accounting for multiple comparisons (20 tests per dependent variable) with a Bonferroni correction, $P \leq 0.003$ was considered significant. The analyses were conducted using SPSS version 16.

\section{Results}

About $67 \%$ of the respondents were males and the average age of the respondents was about 37 years and with a standard deviation of 12.84 . The average family size in a household was about four persons. Regarding the level of education, about $41 \%$ of the respondents went to primary school. Most of the respondents (about 94\%) were engaged in mixed farming. The average annual income of the respondents was about 38,935.00 Ethiopian Birr (ETB). ${ }^{2}$ The majority of the respondents (88\%) had livestock. However, the greater proportion of the respondents $(80 \%)$ claimed that they did not have enough grazing land. In contrast, a considerable percentage (about 59\%) of the respondents felt a need to keep more livestock than they had at present. Accordingly, they noted that having more livestock serves as insurance during crop failure. However, about $73 \%$ of the respondents confirmed that they had a shortage of fodder for their livestock (Table 2).

On average, respondents had lived in the area for about 33 years and with a standard deviation of 14.64. Regarding history of settlement, $80 \%$ of the respondents noted that they had inherited land from their ancestors. Similarly, most of the respondents (94\%) have planned to stay in the area in the future, and $97 \%$ of them noted that they had their own private lands. The largest proportion of the respondents (about 95\%) confirmed that they had allocated their landholdings for woodlot plantations. Nevertheless, about $83 \%$ of the respondents noted that they had a shortage of fuelwood (Table 2).

All of the respondents noted that they knew the WWF. This is because the respondents used the forest for the purpose of fuelwood, fodder for their livestock, construction materials, and as source of medicinal plants. In addition to knowing what the forest means to them, the respondents also had the concepts of forest management. So, about $53 \%$ of the respondents had information about the past forest management practices implemented in WWF. They described that in the past, the WWF was exclusively managed by the government. Thus, at that time, the forest was negatively affected by the local communities (Table 2).

According to the respondents, although past forest management activities were exclusively given for the Ethiopian government, the positive implication was that it made the forest to exist up to now. So, at that time, the local communities used to get the highest benefits from the WWF. However, the respondents noted that the past forest management practices had several negative implications, including the degradation of the forest resource and inequitable use of the forest due to unequal access. Moreover, the forest was used only by some individuals, and the local people did not have good concepts about forest management and their control over the forest resource was also negligible. The majority of the respondents (about 84\%) had information about the concepts of PFM. Hence, $83 \%$ of the respondents strongly agreed to manage the existing forest via participatory approach. Also, about $94 \%$ of the respondents knew that there was a PFM practice and about $78 \%$ of them noted 
Table 2 Socio-economic characteristics and descriptive results

\begin{tabular}{|c|c|c|c|}
\hline Variables & Descriptive result & & Proportion (\%) \\
\hline Total sample size $(\mathrm{N})$ & \multicolumn{2}{|l|}{64 Households } & \\
\hline \multirow[t]{2}{*}{ Sex } & \multicolumn{2}{|l|}{ Male } & 67.19 \\
\hline & \multicolumn{2}{|l|}{ Female } & 32.81 \\
\hline Age & \multicolumn{2}{|l|}{ Mean $=37.22$ years $; S D=12.84$} & \\
\hline Family size & \multicolumn{2}{|l|}{ Mean $=4.27$ persons; $\mathrm{SD}=1.79$} & \\
\hline \multirow[t]{4}{*}{ Levels of education } & \multicolumn{2}{|l|}{ Literate } & 37.50 \\
\hline & \multicolumn{2}{|l|}{ Primary education } & 40.63 \\
\hline & \multicolumn{2}{|l|}{ Secondary education } & 18.75 \\
\hline & \multicolumn{2}{|l|}{ Degree } & 3.13 \\
\hline \multirow[t]{2}{*}{ Occupation type } & \multicolumn{2}{|l|}{ Mixed farming } & 93.75 \\
\hline & \multicolumn{2}{|l|}{ Government employee } & 6.25 \\
\hline Annual income & \multicolumn{2}{|l|}{ Mean $=38,935.00 \mathrm{ETB} ; \mathrm{SD}=15,533.00$} & \\
\hline \multirow[t]{2}{*}{ Livestock ownership } & \multicolumn{2}{|l|}{ Yes } & 87.50 \\
\hline & \multicolumn{2}{|l|}{ No } & 12.50 \\
\hline \multirow[t]{2}{*}{ Had enough grazing land } & \multicolumn{2}{|l|}{ Yes } & 20.31 \\
\hline & \multicolumn{2}{|l|}{ No } & 79.69 \\
\hline \multirow[t]{2}{*}{ Wanted to keep more livestock in the future } & \multicolumn{2}{|l|}{ Yes } & 59.38 \\
\hline & \multicolumn{2}{|l|}{ No } & 40.63 \\
\hline \multirow[t]{2}{*}{ Had a shortage of fodder for livestock } & \multicolumn{2}{|l|}{ Yes } & 73.44 \\
\hline & No & & 26.56 \\
\hline Commonly used methods to manage and satisfy the & Free-range grazing & Yes & 6.25 \\
\hline forage requirement for their IIvestock & & No & 93.75 \\
\hline & Cut and carry system & Yes & 42.19 \\
\hline & & No & 57.81 \\
\hline & Transhumance & Yes & 3.13 \\
\hline & & No & 96.88 \\
\hline & Purchasing additional fodder & Yes & 53.13 \\
\hline & & No & 46.88 \\
\hline & Crop residue & Yes & 54.69 \\
\hline & & No & 45.31 \\
\hline Length of duration of residence in the area (in years) & Mean $=32.72$ years $; S D=14.64$ & & \\
\hline History of settlement & Inherited land from my ancestor & & 79.69 \\
\hline & Settled by my own interest in search of land & & 20.31 \\
\hline Had the plan to stay in the area in the future & Yes & & 93.75 \\
\hline & Unsure & & 0.00 \\
\hline & No & & 6.25 \\
\hline Had private land ownership & Yes & & 96.89 \\
\hline & No & & 3.13 \\
\hline Allocated land for woodlot plantations & Yes & & 95.31 \\
\hline & No & & 4.69 \\
\hline Had a shortage of fuel wood & Yes & & 82.81 \\
\hline & No & & 17.19 \\
\hline
\end{tabular}


Table 2 Socio-economic characteristics and descriptive results (Continued)

\begin{tabular}{|c|c|c|}
\hline \multirow[t]{2}{*}{ Knew about past forest management system } & Yes & 53.13 \\
\hline & No & 46.88 \\
\hline \multirow[t]{3}{*}{ Had information about the concept of PFM } & Yes & 84.38 \\
\hline & Unsure & 1.56 \\
\hline & No & 14.06 \\
\hline \multirow[t]{5}{*}{ Agreed to manage forests via participatory approach } & Strongly agree & 82.81 \\
\hline & Agree & 6.25 \\
\hline & Unsure & 10.94 \\
\hline & Disagree & 0.00 \\
\hline & Strongly disagree & 0.00 \\
\hline \multirow[t]{3}{*}{ Knew that there was PFM practice in the WWF } & Yes & 93.75 \\
\hline & Unsure & 6.25 \\
\hline & No & 0.00 \\
\hline \multirow{5}{*}{$\begin{array}{l}\text { Agreed that the local community accepted the PFM } \\
\text { practice in the WWF }\end{array}$} & Strongly agree & 0.00 \\
\hline & Agree & 78.13 \\
\hline & Unsure & 21.88 \\
\hline & Disagree & 0.00 \\
\hline & Strongly Disagree & 0.00 \\
\hline \multirow[t]{3}{*}{ Benefited due to the implementation of PFM } & Yes & 82.81 \\
\hline & Unsure & 0.00 \\
\hline & No & 17.19 \\
\hline \multirow[t]{10}{*}{ Perceived benefits to the local people due to PFM } & Employment opportunities & 46.89 \\
\hline & Infrastructure development & 85.94 \\
\hline & Wood products & 10.94 \\
\hline & Source of medicinal plants & 84.38 \\
\hline & Source of fodder for livestock through cut and carry & 12.50 \\
\hline & Traditional beehive keeping and source of honey & 25.00 \\
\hline & Access to free-range livestock grazing & 23.44 \\
\hline & Source of income from visiting eco-tourists & 31.25 \\
\hline & Getting free transport during hardship periods & 75.00 \\
\hline & Aesthetic and recreational values & 82.81 \\
\hline \multirow{3}{*}{$\begin{array}{l}\text { Knew that there was problem with the existing PFM } \\
\text { system }\end{array}$} & Yes & 89.06 \\
\hline & Unsure & 1.56 \\
\hline & No & 9.38 \\
\hline \multirow[t]{2}{*}{ Had knowledge about the WWF } & Yes & 96.88 \\
\hline & No & 3.13 \\
\hline $\begin{array}{l}\text { Distance between the edge of the WWF and the } \\
\text { residence area of the respondents }\end{array}$ & Mean $=2.88 \mathrm{~km} ; \mathrm{SD}=7.5$ & \\
\hline \multirow{2}{*}{$\begin{array}{l}\text { Had knowledge to compare the WWF before and after } \\
\text { implementation of PFM }\end{array}$} & Yes & 85.94 \\
\hline & No & 14.06 \\
\hline \multirow[t]{2}{*}{ Knew any other land use types } & Yes & 96.88 \\
\hline & No & 3.13 \\
\hline \multirow[t]{2}{*}{ Had tree planting and growing tradition } & Yes & 95.31 \\
\hline & No & 4.69 \\
\hline
\end{tabular}


Table 2 Socio-economic characteristics and descriptive results (Continued)

\begin{tabular}{|c|c|c|}
\hline \multirow{3}{*}{$\begin{array}{l}\text { Knew that the government had given due recognition } \\
\text { for traditional forest management practices }\end{array}$} & Yes & 93.75 \\
\hline & Unsure & 3.13 \\
\hline & No & 3.13 \\
\hline \multirow{5}{*}{$\begin{array}{l}\text { Agreed that respondents had the responsibility to } \\
\text { protect the WWF }\end{array}$} & Strongly agree & 1.56 \\
\hline & Agree & 92.19 \\
\hline & Unsure & 3.13 \\
\hline & Disagree & 3.13 \\
\hline & Strongly disagree & 0.00 \\
\hline
\end{tabular}

that the local communities agreed to accept the PFM implemented in WWF. The mean distance between the edge of the WWF and the respondents' residential area was about $3 \mathrm{~km}$ (Table 2).

Almost all of the respondents (97\%) had knowledge about the WWF. For example, the respondents noted that the forest harbors different plant and wild animal species. In addition, the local communities directly or indirectly depended on the forest to satisfy their needs. About $86 \%$ of the respondents were able to compare the status of the forest resource before and after the implementation of the PFM system. They noted that the WWF was not wellmanaged before the implementation of PFM. For example, they noted that deforestation, overgrazing, habitat destruction and fragmentation, illegal hunting, and agricultural land expansion were the major threats that accelerated the degradation of WWF. However, after the implementation of the PFM, the local communities were well informed about the concepts of PFM so that the WWF could be properly managed (Table 2).

Most of the respondents (97\%) had other land use types, namely, farm and grazing lands, and they noted that crop cultivation was their major activity since it increases their economy compared with other land use types. Thus, the respondents noted that their engagement in crop production affected the implementation of the PFM in different ways. This is because the local communities spent more time on crop cultivation than being engaged in the PFM. Moreover, they considered the forest as the habitat for the wild animals and insects that damaged their crops. They also wanted to maximize their crop lands on the indiscriminate clearance of the forest. Most of the respondents (95\%) confirmed the existence of tree planting and growing tradition. For example, they noted that they planted and grew trees by using their indigenous knowledge without getting technical assistance from the forestry experts. About $94 \%$ of the respondents reported that the Ethiopian Government had given due recognition to their traditional forest management practices. Furthermore, about 92\% of the respondents agreed that they have the responsibility to protect the WWF. As a result, they have continued to actively participate in the management process and contribute to the conservation and sustainable utilization of the forest resource (Table 2).

Most of the respondents (83\%) confirmed that they got benefits from PFM. Among the most prominent perceived benefits to the local people due to the presence of PFM were, in descending order, infrastructure development, source of medicinal plants, aesthetic and recreational value, getting free transport during hardship period, employment opportunities, source of income from visiting eco-tourists, traditional beehive keeping and source of honey, access to free-range livestock grazing during drought periods when there was a scarcity of fodder for livestock, and source of fodder for livestock through cut-and-carry system and wood products (e.g., fuelwood and construction materials) (Table 2).

Even though a majority of the respondents got different benefits from the PFM practice, $89 \%$ of the respondents reported that there were problems in the implementation of the PFM, including livestock predation by wild animals, death of livestock being infested by insects, crop damage by vermin wild animals, conflicts arising from inequitable benefit-sharing, prohibition of free-access to the forest, loss of time upon the engagement in forest management activities that could otherwise be used for crop cultivation, resource competition, and punishment while one was arrested exploiting the forest resource (e.g., collecting fuelwood, cutting trees, and grazing livestock) without permit (Table 2).

The multiple linear regression model revealed that socio-economic variables significantly affected the perceptions of the local people towards the concept of PFM and the presence of PFM practice. As revealed from their coefficients, education $(\beta=0.36)$, income $(\beta=0.64)$, shortage of fodder for their livestock $(\beta=0.60)$, and benefits due to PFM $(\beta=0.52)$ positively affected the perceptions of the local people towards the concept of PFM. In contrast, family size $(\beta=-0.47)$ and shortage of fuelwood $(\beta=-0.31)$ negatively affected the perceptions of the respondents towards the concept of PFM. Also, those who benefited due to PFM $(\beta=0.52)$ had profound perception towards the presence of PFM. However, 
those who had shortage of fuelwood $(\beta=-0.30)$ significantly had shallow perception towards the presence of PFM in WWF. Overall, the multiple linear regression model revealed that socio-economic variables had significant effects on the two groups of the dependent variables, i.e., perceptions towards the concept of PFM (30\% variance explained) and the presence of PFM practice (11\% variance explained) (Table 3 ).

As revealed from their coefficients, age $(\beta=3.20)$, plan to stay in the area in the future $(\beta=0.22)$, allocation of land for woodlot plantation $(\beta=0.45)$, and tree growing tradition $(\beta=0.90)$ positively affected the perceptions of the local communities towards "the problems with the existing PFM system." In contrast, family size $(\beta=$ $-0.54)$, length of duration of residence $(\beta=-3.31)$ and history of settlement $(\beta=-1.79)$ negatively affected the perception of the local people towards the problems with the existing PFM system. In general, the multiple linear regression model revealed that socio-economic variables had significant effects on the dependent variable, i.e., perception towards "the prevalence of the problems with the existing PFM" (39\% variance explained) (Table 4).

As revealed from their coefficients, those who had enough grazing land $(\beta=0.35)$ and benefited due to PFM $(\beta=0.34)$ significantly had positive attitudes towards managing forests via participatory approach. In contrast, those who had high annual income $(\beta=-0.64)$ significantly had negative attitude towards managing forests via participatory approach. Also, those who had livestock $(\beta=0.58)$, plan to stay in the area in the future $(\beta$ $=0.46)$ and benefited due to PFM $(\beta=0.41)$ significantly had positive attitudes towards having the responsibility to protect WWF. In contrast, those who had shortage of fodder for their livestock $(\beta=-0.54)$, allocated land for woodlot plantations $(\beta=-0.32)$, and had shortage of fuelwood $(\beta=-0.37)$ significantly had negative attitudes towards having the responsibility to protect WWF. Generally, the multiple linear regression model revealed that socio-economic variables had significant effects on the two groups of the dependent variables, i.e., attitudes towards managing forests via participatory approach $(16 \%$

Table 3 Multiple linear regression model (standardized coefficients were reported) to predict the perceptions of local people towards the concept of PFM $\left(R^{2}=0.52\right.$ (Adj. $\left.R^{2}=0.30\right), \mathrm{df}=19 ; F=2.362$, overall $\left.P=0.009\right)$, and implementation of PFM $\left(R^{2}=0.39\right.$ (Adj. $\left.R^{2}=0.11\right)$, $\mathrm{df}=19 ; F=1.385$, overall $P=0.043$ ) in WWF ( $+=$ a positive change in perceptions and $-=$ a negative change in perceptions)

\begin{tabular}{|c|c|c|c|c|c|c|}
\hline \multirow[t]{2}{*}{ Variables } & \multicolumn{3}{|c|}{$\begin{array}{l}\text { Perceptions towards the } \\
\text { concept of PFM }\end{array}$} & \multicolumn{3}{|c|}{$\begin{array}{l}\text { Perceptions towards } \\
\text { implementation of PFM }\end{array}$} \\
\hline & $\bar{B}$ & $t$ & $P$ value & $\bar{B}$ & $t$ & $P$ value \\
\hline Intercept & -2.10 & -1.31 & - & 2.36 & 2.09 & - \\
\hline Sex $($ female $=1$ and male $=2)$ & 0.15 & 1.14 & 0.26 & -0.14 & -1.0 & 0.32 \\
\hline Age & 0.05 & 0.04 & 0.97 & -0.16 & -0.54 & 0.59 \\
\hline Levels of education & 0.36 & $2.75^{\mathrm{a}}$ & 0.003 & -0.18 & -0.80 & 0.43 \\
\hline Family size per household & -0.47 & $-2.20^{\mathrm{a}}$ & 0.003 & -0.21 & -1.08 & 0.29 \\
\hline Occupation & 0.22 & 1.10 & 0.28 & -0.16 & -0.72 & 0.46 \\
\hline Annual income (ETB) & 0.64 & $2.77^{\mathrm{a}}$ & 0.003 & 0.07 & 0.36 & 0.72 \\
\hline Livestock ownership (Yes = 2) & -0.14 & -0.66 & 0.52 & -0.15 & -0.62 & 0.54 \\
\hline Had enough grazing land (Yes = 2) & 0.03 & 0.17 & 0.88 & 0.06 & 0.33 & 0.75 \\
\hline Wanted to keep more livestock in the future $($ Yes $=2)$ & 0.16 & 1.19 & 0.24 & 0.07 & 0.49 & 0.66 \\
\hline Had shortage of fodder for livestock (Yes = 2) & 0.60 & $2.87^{\mathrm{a}}$ & 0.003 & 0.14 & 0.73 & 0.47 \\
\hline Length of duration of residence in the area (years) & 0.29 & 0.21 & 0.84 & 0.23 & 0.14 & 0.89 \\
\hline History of settlement & 0.42 & 0.50 & 0.62 & 0.10 & 0.10 & 0.92 \\
\hline Had the plan to stay in the area in the future & 0.14 & 1.18 & 0.25 & -0.03 & -0.22 & 0.83 \\
\hline Private land ownership (Yes = 2) & 0.11 & 0.29 & 0.78 & 0.07 & 0.20 & 0.84 \\
\hline Allocated land for woodlot plantation (Yes = 2) & -0.01 & -0.09 & 0.93 & -0.07 & -0.52 & 0.61 \\
\hline Had shortage of fuelwood (Yes = 2) & -0.31 & $-2.96^{\mathrm{a}}$ & 0.003 & -0.30 & $-2.94^{\mathrm{a}}$ & 0.003 \\
\hline Benefited due to PFM (Yes = 2) & 0.52 & $4.02^{\mathrm{a}}$ & 0.0001 & 0.52 & $3.02^{\mathrm{a}}$ & 0.002 \\
\hline Knowledge of the respondents on WWF (Yes = 2) & 0.15 & 1.17 & 0.25 & 0.04 & 0.31 & 0.76 \\
\hline Distance between the edge of the WWF and the residential area of the respondents & -0.11 & -0.50 & 0.62 & -0.10 & -0.38 & 0.71 \\
\hline Had a tree planting and growing tradition (Yes $=2$ ) & 0.07 & 0.30 & 0.77 & -0.33 & -1.33 & 0.19 \\
\hline
\end{tabular}

Represents significance at the $95 \%$ confidence level 
Table 4 Multiple linear regression model (standardized coefficients were reported) to predict the perceptions of local people towards the prevalence of problems with the existing PFM system in WWF $\left(R^{2}=0.586\right.$ (Adj. $R^{2}=0.39$ ), $d f=19 ; F=3.039$, overall $P<0.001)$ ( $+=$ a positive change in perceptions and $-=$ a negative change in perceptions)

\begin{tabular}{|c|c|c|c|}
\hline \multirow[t]{2}{*}{ Variables } & \multicolumn{3}{|c|}{ Perceptions towards problems with the existing PFM system } \\
\hline & $\bar{B}$ & $t$ & $P$ value \\
\hline Intercept & -1.41 & 1.28 & - \\
\hline Sex (female $=1$ and male $=2)$ & 0.13 & 1.09 & 0.28 \\
\hline Age & 3.19 & $2.75^{\mathrm{a}}$ & 0.003 \\
\hline Levels of education & -0.17 & -0.87 & 0.39 \\
\hline Family size per household & -0.54 & $-3.02^{\mathrm{a}}$ & 0.002 \\
\hline Occupation & 0.04 & 0.19 & 0.85 \\
\hline Annual income (ETB) & -0.25 & -1.30 & 0.20 \\
\hline Livestock ownership (Yes = 2) & 0.04 & 0.23 & 0.82 \\
\hline Had enough grazing land (Yes = 2) & 0.23 & 1.49 & 0.14 \\
\hline Wanted to keep more livestock in the future $($ Yes $=2)$ & -0.78 & -0.56 & 0.58 \\
\hline Had shortage of fodder for livestock (Yes $=2$ ) & 0.07 & 0.38 & 0.69 \\
\hline Length of duration of residence in the area (years) & -3.30 & $-2.55^{\mathrm{a}}$ & 0.003 \\
\hline History of settlement & -1.79 & $-2.32^{\mathrm{a}}$ & 0.003 \\
\hline Had the plan to stay in the area in the future & 0.22 & $2.01^{\mathrm{a}}$ & 0.003 \\
\hline Private land ownership (Yes $=2$ ) & -0.13 & -0.38 & 0.71 \\
\hline Allocated land for woodlot plantation (Yes $=2$ ) & 0.45 & $4.22^{\mathrm{a}}$ & 0.000 \\
\hline Had shortage of fuelwood (Yes = 2) & -0.21 & -1.43 & 0.16 \\
\hline Benefited due to PFM (Yes = 2) & -0.13 & -1.08 & 0.29 \\
\hline Knowledge of the respondents on WWF (Yes = 2) & -0.002 & -0.02 & 1.0 \\
\hline Distance between the edge of WWF and the residential area of the respondents & 0.28 & 1.36 & 0.18 \\
\hline Had a tree planting and growing tradition (Yes $=2$ ) & 0.90 & $4.35^{\mathrm{a}}$ & 0.0001 \\
\hline
\end{tabular}

${ }^{\mathrm{a}}$ Represents significance at the $95 \%$ confidence level

variance explained), and "having the responsibility to protect the WWF" (40\% variance explained) (Table 5).

As revealed from their coefficients, those who benefited due to PFM $(\beta=0.80)$ significantly had positive attitudes towards accepting the concept and practice of PFM. However, those who had enough grazing land for their livestock $(\beta=-0.24)$ significantly had negative attitudes towards accepting the concept and the practice of PFM. In general, the multiple linear regression model revealed that socio-economic variables had significant effects on the dependent variable, i.e., attitude towards accepting the concept and the practice of PFM (54\% variance explained) (Table 6).

\section{Discussion}

Studies on perceptions and attitudes of local people towards participation in collective forest management activities are limited in Ethiopia in particular and worldwide in general (Kelbessa and Destoop 2007; Tesfaye et al. 2012). The present study explored perceptions and attitudes of local people towards forest conservation and developmental interventions by external agents, identifying sources of conflicts, and proposing solutions in future management and policy decisions in the context of WWF. An attempt was made to explain perceptions and attitudes of the local people that possibly influence engagement in the co-management scheme of the WWF through the PFM approach. This is because perceptions and attitudes are understood to be important antecedents of people's behavior in relation to natural resources management or conservation (Jotte 1997). Thus, many contemporary studies considered perceptions and attitudes of local people as a major topic, mostly, in relation to conservation projects or in the context of wildlife and nature reserve management (e.g., Badola 1998; Gillingham and Lee 1999; Kideghesho et al. 2007; Lee et al. 2009; Mehta and Heinen 2001; Mehta and Kellert 1998; Tesfaye et al. 2012).

The multiple linear regression model revealed that several socio-economic variables significantly affected perceptions and attitudes of local people towards the PFM introduced and implemented in Wof-Washa Kebele. Generally, the study revealed that local people had positive attitudes towards PFM. For example, about three fourth of the respondents agreed to accept and 
Table 5 Multiple linear regression model (standardized coefficients were reported) to predict the attitudes of local people towards managing forests through participatory approach $\left(R^{2}=0.423\right.$ (Adj. $\left.R^{2}=0.16\right), \mathrm{df}=19 ; F=1.579$, overall $\left.P=0.044\right)$, and having the responsibility to protect the WWF $\left(R^{2}=0.535\right.$ (Adj. $\left.R^{2}=0.32\right), \mathrm{df}=19 ; F=2.475$, overall $\left.P=0.006\right)$. ( $+=$ a positive change in attitudes and $-=$ a negative change in attitudes)

\begin{tabular}{|c|c|c|c|c|c|c|}
\hline \multirow[t]{2}{*}{ Variables } & \multicolumn{3}{|c|}{$\begin{array}{l}\text { Attitudes towards managing WWF } \\
\text { through participatory approach }\end{array}$} & \multicolumn{3}{|c|}{$\begin{array}{l}\text { Attitudes towards having the } \\
\text { responsibility to protect WWF }\end{array}$} \\
\hline & $B$ & $t$ & $P$ value & B & $t$ & $P$ value \\
\hline Intercept & 1.76 & 1.51 & - & 4.85 & 2.83 & - \\
\hline Sex $($ female $=1$ and male $=2)$ & -0.15 & -1.05 & 0.30 & -0.13 & -1.003 & 0.32 \\
\hline Age & 1.32 & 0.97 & 0.34 & 0.007 & 0.01 & 1.0 \\
\hline Levels of education & 0.07 & 0.30 & 0.77 & 0.33 & 1.63 & 0.11 \\
\hline Family size per household & 0.26 & 1.23 & 0.23 & 0.16 & 0.87 & 0.39 \\
\hline Occupation & -0.14 & -0.62 & 0.54 & -0.06 & -0.27 & 0.79 \\
\hline Annual income (ETB) & -0.64 & $-2.79^{a}$ & 0.003 & 0.03 & 0.19 & 0.85 \\
\hline Livestock ownership (Yes = 2) & -0.06 & -0.27 & 0.79 & 0.58 & $2.82^{\mathrm{a}}$ & 0.003 \\
\hline Had enough grazing land (Yes = 2) & 0.35 & $2.91^{\mathrm{a}}$ & 0.003 & -0.17 & -1.05 & 0.30 \\
\hline Wanted to keep more livestock in the future $($ Yes $=2)$ & -0.02 & -0.17 & 0.87 & 0.004 & 0.03 & 0.98 \\
\hline Had shortage of fodder for livestock (Yes $=2$ ) & 0.13 & 0.61 & 0.54 & -0.54 & $-2.93^{\mathrm{a}}$ & 0.003 \\
\hline Length of duration of residence in the area (years) & -1.34 & -0.88 & 0.39 & -0.47 & -0.34 & 0.73 \\
\hline History of settlement & -0.70 & -0.77 & 0.45 & -0.14 & -0.17 & 0.86 \\
\hline Had the plan to stay in the area in the future & -0.20 & -1.50 & 0.14 & 0.46 & $3.90^{\mathrm{a}}$ & 0.0001 \\
\hline Private land ownership (Yes $=2$ ) & 0.05 & 0.13 & 0.90 & -0.28 & -0.76 & 0.45 \\
\hline Allocated land for woodlot plantation (Yes = 2) & 0.05 & 0.39 & 0.70 & -0.32 & $-2.79^{a}$ & 0.003 \\
\hline Had shortage of fuelwood (Yes = 2) & 0.07 & 0.43 & 0.67 & -0.37 & $-2.96^{\mathrm{a}}$ & 0.003 \\
\hline Benefited due to PFM (Yes=2) & 0.34 & $2.41^{a}$ & 0.003 & 0.41 & $3.26^{\mathrm{a}}$ & 0.002 \\
\hline Knowledge of the respondents on WWF (Yes = 2) & 0.02 & -0.17 & 0.87 & 0.04 & 0.33 & 0.74 \\
\hline $\begin{array}{l}\text { Distance between the edge of the WWF and the residential area of the } \\
\text { respondents }\end{array}$ & 0.32 & 1.28 & 0.21 & 0.03 & 0.12 & 0.91 \\
\hline Had a tree planting and growing tradition $(Y e s=2)$ & 0.19 & 0.78 & 0.44 & 0.34 & 1.52 & 0.14 \\
\hline
\end{tabular}

${ }^{a}$ Represents significance at the $95 \%$ confidence level

practice PFM in WWF. The positive attitudes of the local people towards PFM may be connected with the perceived benefits (e.g., employment opportunities, infrastructure development, wood products, source of fodder for livestock through cut and carry system, traditional beehive keeping and source of honey, source of income from visiting eco-tourists by providing guiding service, and horse renting) and the various perceived values (e.g., recreational, aesthetic, and medicinal) that the local people expect from the PFM in WWF. The values refer to things that people consider being precious and are the most important and central element in a person's system of attitude (Oskamp 1977). It is also widely documented that the decision by people on whether or not to participate in developmental activities is largely determined by perceived benefits (Dale 2000; Pongquan 1992).

The study generated relevant and informative knowledge about PFM. For example, the respondents noted that deforestation, overgrazing, habitat destruction and fragmentation, and agricultural land expansion were the major causes for the degradation of WWF before the introduction of PFM. While focusing on perceptions and attitudes of the local people towards PFM, the present study contributed to improved knowledge of human dimensions. This may motivate forest managers to include the local people during the process of formulating PFM strategy and plan. In the context of communitybased forest management, participants' understanding or perception of the purpose and the implication of the arrangement with respect to their interest and, thus, the attitudes they form influence the willingness and commitment for its implementation (Gellich et al. 2005; Husain and Bhattacharya 2004; Tesfaye et al. 2012).

Most of the respondents were aware of the PFM in Wof-Washa Kebele, and they expressed their keen interest in its implementation in order to combat the threatening environmental problems and obtain fodder and other useful forest products. For example, the communities had developed positive attitudes towards PFM as 
Table 6 Multiple linear regression model (standardized coefficients were reported) to predict the attitudes of local people towards accepting the concept and practice of PFM in WWF $\left(R^{2}=0.685\right.$ (Adj. $\left.R^{2}=0.54\right), \mathrm{df}=19 ; F=4.678$, overall $\left.P<0.001\right)(+=$ a positive change in attitudes and $-=$ a negative change in attitudes)

\begin{tabular}{|c|c|c|c|}
\hline \multirow[t]{2}{*}{ Variables } & \multicolumn{3}{|c|}{ Attitudes towards accepting the concept and practice of PFM } \\
\hline & $\bar{B}$ & t & $P$ value \\
\hline Intercept & 1.64 & 1.14 & - \\
\hline Sex (female $=1$ and male $=2)$ & 0.01 & 0.06 & 0.95 \\
\hline Age & -0.53 & -0.53 & 0.60 \\
\hline Levels of education & 0.003 & 0.02 & 1.0 \\
\hline Family size per household & -0.16 & -1.06 & 0.3 \\
\hline Occupation & -0.05 & -0.316 & 0.76 \\
\hline Annual income (ETB) & 0.09 & 0.55 & 0.59 \\
\hline Livestock ownership (Yes = 2) & -0.05 & -0.31 & 0.76 \\
\hline Had enough grazing land (Yes = 2) & -0.24 & $-2.99^{\mathrm{a}}$ & 0.003 \\
\hline Wanted to keep more livestock in the future $($ Yes $=2)$ & 0.08 & 0.79 & 0.43 \\
\hline Had shortage of fodder for livestock (Yes $=2$ ) & 0.04 & 0.29 & 0.78 \\
\hline Length of duration of residence in the area (years) & 0.68 & 0.60 & 0.55 \\
\hline History of settlement & 0.54 & 0.79 & 0.43 \\
\hline Had the plan to stay in the area in the future & 0.10 & 1.03 & 0.31 \\
\hline Private land ownership (Yes $=2$ ) & 0.12 & 0.40 & 0.69 \\
\hline Allocated land for woodlot plantation (Yes $=2$ ) & -0.003 & -0.03 & 0.98 \\
\hline Had shortage of fuelwood (Yes = 2) & 0.06 & 0.49 & 0.63 \\
\hline Benefited due to PFM (Yes = 2) & 0.80 & $7.63^{\mathrm{a}}$ & 0.0001 \\
\hline Knowledge of the respondents on WWF (Yes = 2) & 0.04 & 0.38 & 0.71 \\
\hline Distance between the edge of the WWF and the residential area of the respondents & -0.13 & -0.70 & 0.49 \\
\hline Had a tree planting and growing tradition (Yes $=2$ ) & -0.21 & -1.15 & 0.26 \\
\hline
\end{tabular}

${ }^{\mathrm{a}}$ Represents significance at the $95 \%$ confidence level

most of the respondents believed that trees preserve soil fertility and reduce the susceptibility of the land to wind and water erosion. Thus, a majority of the respondents expressed their readiness and willingness to participate in forest management through implementation of PFM. The form of contribution ranges from contribution of cash and efforts to any type of contribution if asked.

Acceptance of PFM by the respondents was clear in Wof-Washa Kebele, and many of them preferred the forest to be owned and managed by them. They reported the importance of having links with the non-government organizations (NGOs) (e.g., SUNARMA (Sustainable Natural Resources Management Association) which is a local NGO that engages in the conservation of WWF via PFM, and also, it provides training to the local communities about WWF and its various values to the local people), and this, in fact, was a reflection of their positive attitudes towards the PFM. They preferred NGOs to play their roles in coordination, technical support, and implementation of laws. The majority of the respondents thought that the PFM coordinated the NGOs, such as SUNARMA is the best approach to ensure participation and protection of the WWF from damage and illegal use. This is a useful result for forest conservation managers, land use planners as well as policy and decision makers because the change in attitudes and perceptions of the rural people towards PFM is important for the conservation and sustainable utilization of the remnant WWF. Also, this result indicated a change in the feeling of fear that the NGOs would take their lands and the difficulty of management if the forest were left to the people alone. Surprisingly, there were no respondents that did not accept the PFM although about $22 \%$ of the respondents were unsure of whether or not to accept the PFM being implemented due to their limited awareness about the practice.

As hypothesized, our results revealed that there was a difference in the perceptions of the local people towards PFM based on socio-economic variables. The results revealed that among the selected variables expected to affect participation, gender had a positive significant effect. This could be attributed to the fact that men play a central role in tree planting, and women are not fully involved in tree growing in the surveyed village. For 
example, Skutch (1983) emphasized that men, whose authority was not easily changeable, retain the sole right to grow, manage, and fell trees. Therefore, it is safe to say that women would have been interested in getting cheap fuelwood, and tree planting may, therefore, be better tended by men (Woltamo 1997).

Age proved to have a positive significant effect on respondents' perception towards PFM. This could be explained by the migration of the youth to the nearest towns to seek for employment opportunities so as to improve their financial situation leaving only older men and women in the villages. Hence, they have to bear all the burden of farming and planting of trees. The results also revealed that the level of education had positive effect on the perception of the respondents towards the concept of PFM. This could be due to interest to know and participate in PFM increases with increase in the level of education. Moreover, respondents who had shortage of fodder for their livestock had positive perception towards the concept of PFM. This could be attributed to the fact that, if the forest is protected by PFM system, they will be benefited during hardship period, for example, when there is a shortage of fodder for their livestock.

However, family size and respondents who had shortage of fuelwood had negative perceptions towards the concepts of PFM. This could be attributed to the fact that when family size increases, households want to expand their agricultural land and, thus, they are not interested to participate in PFM, which restricts getting access to the forest land for expanding agriculture. Moreover, those that had shortage of fuelwood assumed that they could easily get access to the forest if the PFM was not implemented. They are not interested in knowing about PFM since they believe that the cause of their problem was the establishment of PFM in the area. These perception problems could be due to the low levels of awareness about PFM. Also, respondents that had large family size lived in the area for a long period of time and inherited their lands from their ancestor perceived various problems due to the existence of PFM. Hence, more awareness creation is required about PFM in order to avoid these negative perceptions.

In forest management, attitudes of people are either positive or negative outlook to particular forest management activities (Elias 2004; Jotte 1997; Tesfaye et al. 2012). Therefore, in support of our second hypothesis, the results revealed that there is variation in attitudes of local people towards PFM, depending on their previous benefit-sharing experience (i.e., access to and control over the forest resource) from PFM, and distance from the edge of the WWF. Accordingly, the results suggested that attitudes of the local people were significantly affected by previous experience on benefit-sharing. Since the benefits obtained from the WWF were not equally distributed among the local communities, those who previously benefited from the forest had positive attitudes towards PFM. For example, the respondents claimed that authorized people and the relatives of guards to the WWF were the major benefited groups. However, after the implementation of the PFM, almost all the local communities obtained benefits from the forest fairly and participated in the forest management activities. Hence, those individuals who got the highest benefits from the forest before the implementation of PFM were less interested to accept the concept of PFM. Those respondents with high access to, who control over and are far from the edge of the WWF had positive attitudes towards PFM than those who had less access to, control over, but were nearest to the edge of the forest. For example, those individuals who were farthest from the edge of the forest could not easily notice the problems related with the implementation of the PFM activities and, hence, they decided easily to manage forests via participatory approach without getting worried. However, those individuals who had little access to and control over the forest had developed negative attitudes towards managing the forest through implementation of PFM since they believed that the costs that they invest in the management of the forest would be greater than the benefits that they obtain.

In another instance, the results revealed that respondents with high annual income had negative attitudes towards managing the forest via participatory approach. This is because they gave less emphasis about the PFM by only considering its economic importance, suggesting that the respondents need awareness about the different values of PFM. Similarly, those respondents who had enough grazing land had negative attitudes towards the concept of PFM. One possible explanation is that they may fear that the introduction of PFM will inevitably minimize the area of grazing land in the future. Also, respondents who allocated land for woodlot plantation had shortage of fuel wood and had shortage of fodder for their livestock had negative attitudes towards taking the responsibility of forest management through the implementation of PFM. This could be due to the fact that they think only for their private lives and immediate benefits rather than considering the benefits of the general public and also the long-term benefits that could be generated when forests are managed through PFM. In addition, lack of detail information about the concept of PFM and its positive implications on the livelihood of the local people could be another possible reason. In contrast, respondents who benefited from the implementation of PFM, i.e., those who had livestock and plan to stay in the area in the future had positive attitudes towards taking the responsibility to protect the WWF. 
Generally, perceptions and attitudes of the local people towards PFM can be positively influenced by increasing their knowledge (Tesfaye et al. 2012). More importantly, public awareness programs and conservation education can assist in improving perceptions and attitudes of young people towards PFM. Promoting direct participation of the local residents in decision-making and implementation of PFM strategic plan can also mitigate potential conflicts and assure long-term public supports towards PFM. By comparing the perceptions and attitudes quantified and presented in this baseline study as well as results from future replication of this study, researchers can provide relevant information for decision makers and forest conservation managers to deal with potential conflict of interests between PFM and the needs of the local people.

\section{Conclusions}

Investigating perceptions and attitudes of local communities is crucial to manage forest resource through the implementation of PFM (Tesfaye et al. 2012). In the present study, the multiple linear regression model revealed that several socio-economic variables significantly affected either positively or negatively perceptions and attitudes of local people towards the PFM implemented in Wof-Washa Kebele. Most of the negative perceptions and attitudes towards PFM might have happened due to the low level of awareness of the local people about the PFM and the long period of dependency on the forest resource in the area. The results suggested that respondent acceptance of PFM was very clear, and a majority of them preferred the forest to be owned and managed by them. In fact, most of the respondents had positive perceptions and attitudes towards the concept and implementation of PFM. Many of the respondents agreed that they benefited due to the implementation of PFM. Their benefits ranged from satisfying their basic domestic needs to using the forest for grazing and aesthetic value, e.g., as source of pleasure from the beautiful landscape. In line with the findings of the present study, it is evident that PFM played a paramount economic role in the lives of the local communities. However, due to their low level of knowledge, the economic benefits derived from the WWF had not been appreciated in the past by the local communities.

The present study investigated appropriate management strategies and techniques about PFM that may assist forest managers, local communities, private, and public sectors in addressing opportunities and challenges for conserving and managing forests. Other than academic purposes, it is believed that the findings of this study generated quantitative scientific information for policy-makers and planners that guides them towards better and more informed decision-making for PFM establishment and implementation that is geared towards communal forest management and, thereby, to achieving the broader goal of poverty reduction in Ethiopia. Therefore, effective conservation and sustainable use of the forest need the full involvement of many stakeholders, including the local communities.

Based on the findings of the present study, the following are recommended:

$>$ Increasing the knowledge and awareness level of the local communities about PFM, which is crucial to introduce and effectively implement community-based forestry practices.

$>$ Programmers and their implementation foresters should develop a two-way communication system with farmers to move ahead with PFM.

$>$ Farmers should be involved in problem definition, the design of possible solutions, and evaluation of the proposed technological solutions.

$>$ Extension agents should treat farmers as people with valuable information and knowledge about forest management since they are vital for providing insights on how the needs of the people can be met, which includes maintaining sound environmental conditions. $>$ Women should be involved in community programmes as decision makers and implementers since fuelwood collection and consumption is their own responsibility, and they also remain in the villages all year round.

$>$ Integration of indigenous knowledge with modern conservation approaches in the planning and implementation process is crucial to improve and promote local participation in conservation and management of forests; local knowledge not only provides relevant information on the use of the forest but also contributes valuable information on how to maintain and conserve it.

$>$ Introducing and promoting community-based conservation efforts that allow communities to derive economic benefits from eco-tourism since they may promote forest conservation while, at the same time, providing a solution to resource use conflicts around WWF.

$>$ Developing the forest for nature-based tourism seems to be a promising business in the future since eco-tourism activities can also improve and diversify the incomes of the local people through creating job opportunities, such as tourist guiding services, souvenir selling, and horse renting all of which can help make eco-tourism economically viable in WWF; developing hiking trails and interpretive materials, including field guides to birds, wild mammals, and woody species would be valuable assets for practicing community-based eco-tourism in the WWF. 
$>$ Since socio-economic variables that affect perceptions and attitudes of local people towards PFM may change over time, future research is crucial to consider the time dimension as another factor while studying perceptions and attitudes of local people towards the PFM in the study site and elsewhere.

\section{Endnotes}

${ }^{1}$ Kebele refers to the lowest administrative structure in Ethiopia.

${ }^{2} 1 \mathrm{USD}=22.71 \mathrm{ETB}$ at the time of the study.

\section{Acknowledgements}

First of all, the authors would like to forward their gratitude to the local people residing in Wof-Washa Kebele for sharing their fruitful ideas and abundant experiences about their perceptions and attitudes towards PFM in their localities during the questionnaire-based household survey. The authors also wish to forward their warm gratitude to the office of Sustainable Natural Resources Management Association (SUNARMA)—Debre Berhan Branch, for sharing practical information about PFM around WWF. The data enumerators are gratefully acknowledged for their assistance during the household survey. Last but not the least, the authors would like to thank the editor-in-chief of the Journal of Ecological Processes and the anonymous reviewer/s for their valuable comments and critics that helped much to improve the earlier version of the manuscript.

\section{Funding}

The authors would like to forward their gratitude to Debre Berhan University for covering all sources of the research funding that helped in the design of the study and collection, analyses, and interpretation of the data and also in writing of the manuscript.

\section{Authors' contributions}

SAT designed and conducted the field research, analyzed the data, and drafted the manuscript. DT interpreted the results and helped in the manuscript writing. Both authors read, revised, and approved the final manuscript.

\section{Competing interests}

The authors declare that they have no competing interests.

\section{Publisher's Note}

Springer Nature remains neutral with regard to jurisdictional claims in published maps and institutional affiliations.

\section{Author details}

${ }^{1}$ Department of Natural Resources Management, College of Agriculture and Natural Resource Sciences, Debre Berhan University, P.O. Box 445, Debre Berhan, Ethiopia. ${ }^{2}$ Department of Crop Science and Production, Botswana University of Agriculture and Natural Resources, Private Bag 0027, Gaborone, Botswana.

Received: 21 February 2017 Accepted: 13 April 2017

Published online: 12 May 2017

\section{References}

Ameha A, Larsen HO, Lemenih M (2014) Participatory forest management in Ethiopia: learning from pilot projects. Environ Manag 53:838-854

Anders S (2000) Guidelines for participatory forest management planning. FARMAfrica, Addis Ababa

Badola R (1998) Attitude of local people towards conservation and alternative forest resource: a case study from the lower Himalaya. Int J Biodivers Conserv 7:1245-1259

Bekele T (1994) Vegetation ecology of remnant Afromontane forests on the Central Plateau of Shewa, Ethiopia. Acta Phytogeogr Suec 79:1-59

Center for International Forestry Research (CIFOR) (2001) Forest for the future, CIFOR annual report., p 56
Chaffey DR (1979) South-west Ethiopia forest inventory project: a reconnaissance inventory of forest in south-west Ethiopia. Ministry of Overseas Development, Land Resources Development Centre, Project Report 31, England.

Cohen L, Manion L, Morrison K (2000) Research methods in education, 5th edn Routledge Falmer, UK, London

Daily GC (1995) Restoring value to the world's degraded lands. Science 269:350-354

Dale R (2000) Organizations and development: strategies, structures and processes. Sag publication, New Delhi

Elias K (2004) People's perception of forest and livelihood in joint forest management area, Chilimo, Ethiopia. Swedish University of Agricultural Sciences, Skinnskatterberg. Unpublished MSc Thesis. Available at https:// www.google.com/search?q=g\&gws_rd=ssl\#q=Elias+K+2004)+ People\%E2\%80\%99s+perception+of+forest+and+livelihood+in+joint+forest +management+area,+Chilimo,+Ethiopia.+Swedish+University+of+Agricultural +Sciences,+Skinnskatteberg.+Unpublished+MSc+Thesis. Accessed 15 Jan 2017

Fiallo EA, Jacobson SK (1995) Local communities and protected areas: attitudes of rural residents towards conservation and Machalilla National Park, Ecuador. Environ Conserv 22:241-249

Food and Agriculture Organization (FAO) (1988) Report on the mission to Ethiopia on Tropical Forestry Action Plan. FAO, Rome

Gadd ME (2005) Conservation outside of parks: attitudes of local people in Laikipia, Kenya. Environ Conserv 32:50-63

Gellich S, Edwards J, Kaiser GMJ (2005) Importance of attitudinal differences among artisanal fishers towards co-management and conservation of marine resources. Conserv Biol 19:865-875

Gillingham MS, Lee PC (1999) The impact of wildlife-related benefits on the conservation and attitude of local people around the Selouse Game Reserve, Tanzania. Environ Conserv 26:218-228

Henery PWT (1973) Proposal for a forest inventory project in south-western Ethiopia. Land Resources Division, Foreign Commonwealth Office, Overseas Development Administration, Project Proposal PROP 11/73.

Hillman JC (1993) Compendium of wildlife conservation information, vol 1. NYZS and EWCO, Addis Ababa, p 580

Hills AM (1995) Empathy and belief in the mental experience of animals: reviews and research reports. Anthrozoös 8:132-142

Hren D, Lukic IK, Marusic A, Vodopivec I, Vujaklija A, Hrabak M, Marusic M (2004) Teaching research methodology in medical schools: students' attitudes towards and knowledge about science. Med Educ 38:81-86

Husain Z, Bhattacharya RM (2004) Attitudes and institutions: contrasting experience of joint forest management in India. J Environ Devel Econ 9:563-577

Irwin B (2000) The experiences of FARM-Africa, SOS-Sahel and GTA 4: developing PFM

Jotte Z (1997) Folklore and conservation in Nigeria: using PRA to learn from elders, ichire orating and the students. The Federal University of Agriculture, London

Kelbessa E, Destoop C (2007) Participatory forest management (PFM), biodiversity and livelihoods in Africa. Proceeding in international conference. 19-21 March 2007, Addis Ababa.

Kelley J, Scoones I (2000) Knowledge, power and politics: the environmental policy making process in Ethiopia. J Mod Afr Stud 38:89-121

Kideghesho J, Roskaft RE, Kaltenbornb P (2007) Factors influencing conservation attitudes of local people in Western Serengeti, Tanzania. Int J Biodivers Conserv 16:2213-2230

Knight SE, Vrij A, Cherryman J, Nunkoosing K (2004) Attitudes towards animal use and animal mind. Anthrozoös 17:43-62

Lee TM, Sodhi NS, Prawiradilaga DM (2009) Determinants of local people attitudes towards conservation and the consequential effects on illegal resource harvesting in the protected area of Sulawesi (Indonesia). J Environ Conserv 36:157-170

Mamo Y (2015) Attitudes and perceptions of the local people towards benefits and conflicts they get from conservation of the Bale Mountains National Park and mountain nyala (Tragelaphus buxtoni), Ethiopia. Int J Biodivers Conserv $7: 28-40$

Mehta JN, Heinen JT (2001) Does community-based conservation shape favorable attitudes among locals? An empirical study from Nepal. Environ Manag 28:165-177

Mehta JN, Kellert SR (1998) Local people attitudes towards community-based conservation policy and programmes in Nepal: a case study in the MakaluBarun conservation area. Environ Conserv 36:320-333

Nelson N, Wright S (1995) Power and participation. In: Nelson N, Wright S (eds) Power and participatory development: theory and practice. Intermediate Technology Publications, London, pp 1-18 
Oskamp S (1977) Attitudes, values and opinions. N. J. Prentice Hall, Englewood cliffs Pongquan S (1992) Participatory development activities at local level: a case study in villages of central Thailand, Bangkok, Thailand

Roskaft E, Handel B, Bjerke T, Kaltenborn BP (2007) Human attitudes towards large carnivores in Norway. Wild Biol 13:172-185

Siraj M, Zhang K, Xiao W, Bilal A, Gemechu S, Geda K, Yonas T, Xiaodan L (2016) Does participatory forest management save the remnant forest in Ethiopia? Proceedings of the National Academy of India-Section B: Biological Sciences, pp 15

Skutch M (1983) Why people do not plant trees? Village case studies. Tanzanian resource for future. Washington $\mathrm{DC}$

Tadesse SA, Kotler BP (2016) Attitudes of local people towards the mountain nyala (Tragelaphus buxtoni) in Munessa, Ethiopia. Afr J Ecol 54:488-499

Takahashi R, Todo Y (2012) Impact of community-based forest management on forest protection: evidence from an aid-funded project in Ethiopia. Environ Manag 50:396-404

Teketay D, Bekele T (1995) Floristic composition of Wof-Washa natural forest, Central Ethiopia: implications for the conservation of biodiversity. Feddes Repertorium 106:127-147

Tesfaye $Y$ (2011) Participatory forest management for sustainable livelihoods in the Bale Mountains, Southern Ethiopia. Swedish University of Agricultural Sciences, Uppsala, p 109. Unpublished Doctoral Dissertation. Available at https://scholar.google.com/scholar?q=Tesfaye+Y+2011)+Participatory +forest+management+for+sustainable+livelihoods+in+the+Bale +Mountains,+Southern+Ethiopia.\&hl =en\&as_sdt=0\&as_vis=1\&oi= scholart\&sa=X\&ved=0ahUKEwjKm43Y_b_TAhWKKsAKHWWCBApsQgQMIIDAA. Accessed 20 Jan 2017

Tesfaye Y, Roos A, Campbell BM, Bohlin F (2010) Forest incomes and poverty alleviation under participatory forest management in the Bale Highlands, Southern Ethiopia. Int For Rev 12:66-77

Tesfaye Y, Anders R, Folke B (2012) Attitudes of local people towards collective action for forest management: the case of PFM in Dodola area in the Bale Mountains, Southern Ethiopia. Int J Biodivers Conserv 21:245-265

Von Breitenbach F (1962) National forestry development planning, a feasibility and priority studyon the examples of Ethiopia. Ethiop For Rev 3(4):41-68

Walpole MJ, Goodwin HJ (2001) Local attitudes towards conservation and tourism around Komodo National Park, Indonesia. Environ Conserv 28:160-166

Winberg E (2010) Participatory forest management in Ethiopia, practices and experiences. Food and Agriculture Organization of the United Nations, Subregional Office for Eastern Africa, Addis Ababa, p 58

Woltamo T (1997) The development of gender knowledge and gender typed beliefs in preschool years. Addis Ababa University, Addis Ababa. Unpublished MSc Thesis. Available at https://www.google.com/search?q=g\&gws_rd= ssl\#q=Woltamo+T+(1997)+The+development+of+gender+knowledge+and +gender+typed+beliefs+in+preschool+years.+Addis+Ababa+University,+ Addis+Ababa.+Unpublished+MSc+Thesis. Accessed 16 Dec 2016

\section{Submit your manuscript to a SpringerOpen ${ }^{\mathcal{O}}$ journal and benefit from:}

- Convenient online submission

- Rigorous peer review

- Immediate publication on acceptance

- Open access: articles freely available online

- High visibility within the field

- Retaining the copyright to your article 